\title{
Psychic Trauma of Youngsters in R.K. Narayan's The World of Nagaraj
}

\section{OPEN ACCESS}

Manuscript ID:

ENG-2020-08043327

Volume: 8

Issue: 4

Month: September

Year: 2020

P-ISSN: 2320-2645

E-ISSN: 2582-3531

Received: 27.06 .2020

Accepted: 25.08.2020

Published: 01.09.2020

Citation:

K, Gabriel Karthick.

"Psychic Trauma of

Youngsters in R.K.

Narayan's The World

of Nagaraj." Shanlax

International Journal

of English, vol. 8, no. 4,

2020, pp. 49-51.

DOI:

https://doi.org/10.34293/

english.v8i4.3327

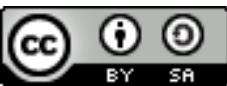

This work is licensed under a Creative

Commons Attribution-

ShareAlike 4.0

International License

\section{Gabriel Karthick K}

Assistant Professor of English, Voorhees College, Vellore, Tamil Nadu, India

https://orcid.org/0000-0003-0271-9740

\begin{abstract}
The article examines the psychic trauma of youngsters during the crucial stage of their life. It gives a deep insight into the practical issues faced by youngsters, as explained by R.K. Narayan in his novel. It describes the complex transition of an adolescent mind into adulthood. The themes of the novel The World of Nagaraj are closely attached to real-life experiences of youngsters and also engross the psychology of young minds. The main objective is to analyze the common psychic issues of youngsters in the Indian context.
\end{abstract}

Keywords: Psychic trauma, Youngsters, Nagaraj and Tim

The latest of R.K. Narayan's magnificent Malgudi books, The World of Nagaraj, is beautifully written, funny, and haunting. It evokes in marvelously rich detail of the atmosphere of a small town in southern India. The novel creates a magical world into which the reader is instantly drawn. One of the famous international literary journal Times Literary Supplement based on London had praised Narayan's work The World of Nagaraj as Narayan's genius, which plays gently over this novel, lies in his persuading us that the lives and characters of Malgudi represent substantial human nature, that what happens in India happens in Malgudi and what happens in Malgudi happens everywhere.

The character of Tim was well constructed than any other character in the novel. It is more attractive than that of the protagonist, Nagaraj. Tim is the son of Nagaraj's ambitious brother Gopu. You, after the birth of Tim, moved to the village to get rid of the disturbing town life. Nagaraj and his wife Sita were childless. They were very fond of Gopu's son, Tim. They loved him so much, and Tim too loved them.

They want their elders to be so liberal and lovable towards them. They do not want the elders to correct them. They want to experience the so-called 'real freedom' without correction, punishment, and condemnation. They desire to be in a world free from all sorts of restrictions - the real nature of youngsters exposed through the character of Tim in The World of Nagaraj.

Youngsters turn very adamant because of certain reasons. It is very difficult to turn them away from their adamancy. In their crucial stage of being a youngster, they do not want anyone, including their parents, to interfere in their inner world, which is full of fun and entertainment. They hate to be scolded by the elders for their faults. The elders' behavior or character is the main reason for the youngsters' mind set-up. They are largely influenced by the lifestyle and nature of elders. Nowadays, youngsters hate to live in villages. They choose to live in cities and towns because of modernity. Tim's father, Gopu, believed that it was Nagaraj's lifestyle and nature that influenced Tim to hate village life and love to live in a town like Malgudi. 
Mostly youngsters live a life of duplicity. They never reveal their so-called 'secret life' to anyone, particularly parents and elders in the family. Tim lived a double life. Nagaraj thought Tim was regularly attending college and had been concentrating on studies, but his beliefs proved to be false. It was too late when he found out the secrets of Tim. He failed to have an eagle's eye on Tim because of his hesitation and fear of his backlash.

Youngsters get addicted to evil habits because of bad acquaintance. Evil habits such as smoking, drinking alcohol, drugs, and other habits are introduced to youngsters only through two possible channels - one is the bad acquaintance, and another is their elders' practices. Ultimately, addiction to evil habits will lead youngsters to tremble and fall in their life at the beginning itself. Tim, too was addicted to such practices because of bad acquaintance. It was such evil habits that made him live secret life forbidden to his uncle Nagaraj and aunt Sita. The only reason for his secret late-night activities is an addiction to evil habits, particularly alcohol consumption.

Youngsters are suffering from a psychic trauma of wasting things or money when they are given excess or when their needs exceed the limit. Very often, in most families, particularly the rich class and high-middle class, parents are unaware of their children's needs. They feed them with excess and even meet their need exceeding the limit. Youngsters take advantage of such situations and even become ignorant of the values of things and money spent on them. Tim, too lived such a useless and ignorant life as he misused his uncle's passion towards him. He was ignorant of the values of things and money spent on him by his uncle, Nagaraj.

At the same time, Nagaraj has to be blamed for his 'too much concern' on his nephew, Tim. He was unaware of what Tim needs and what he doesn't. He wasted his money, which in turn made Tim an unruly and irresponsible boy. Nagaraj didn't even know that his nephew had discontinued his college. The elders of the family should be blamed for their ignorance and irresponsible attitude towards their children. Youngsters enter into a state of psychic instability because of the attitude of the elders. When elders just turn blind, dumb, and deaf to the activities of youngsters, they feel themselves as being caught up in a state of freedom to do whatever they like to.

When people complain about the activities of children in a family, it is the duty of the elders, particularly parents, to properly respond and react effectively to their complaints. They must warn or at least scold the children of their bad activities. If they are in an extreme condition, they should be punished to some extent. Therefore, it is the parents who have to correct and control their children in bad ways.

Likewise, Nagaraj, being the uncle of Tim, received many complaints about Tim from Nagaraj's friends, neighbors, and relatives. He ignored everything, and he didn't even have the courage to either warn or scold Tim for his wrongful deeds. It was because of this attitude of Nagaraj, Tim became a bad boy. Nagaraj had been so compassionate and sympathetic towards Tim.

Tim took advantage of his uncle's extreme fondness towards him and began to commit wrongful deeds without hesitation. He did not have a fear of being punished or scolded. At some point in time, Tim became an uncontrolled and extreme wrongdoer. Narayan has depicted the attitude of Nagaraj and the extreme wrongdoing nature of Tim.

Youngsters have the habit of evading questions asked about their characters and activities. They hate to reply to certain questions that they believe to be intruding into their privacy. They will either give irrelevant answers or try to outsmart elders by their witty replies. When Tim was asked certain questions by his uncle, he tried to outsmart his uncle by giving irrelevant replies. Tim had discontinued his college studies without informing either his father Gopu or his uncle Nagaraj. He pretended to be regularly attending classes and doing well in his studies. Nagaraj was shocked to hear about his nephew's drop out when his friend Jesudoss suddenly exposed the truth. Nagaraj did not know what to do, for it was he who would be blamed for everything that Tim did.

He was taken aback to hear his nephew's secret discontinuation of college studies. He was under the impression that Tim had been regularly attending class. Tim had destroyed his life and career. He became such an unruly fellow who did not even mind to take such a horrible decision without informing either his father or his uncle. 
Youngsters are suffering from a psychic struggle of making horrible decisions without thinking about the worst consequences that they have to face in the future. They don't even worry about their future and the status of the family. They want to be the masters of their lives. They don't want instigation and dictation from their elders, including their parents. They feel very disgusting when elders attempt to influence them. Therefore, they intend to get rid of the parent's care and elder's correction. They prefer to lead a care-free life. Tim has proved to be an apt example of such trauma faced by youngsters.

Nowadays youngsters are very much sensitive and become nervous even for minute things spoken against them. They even go to the extent of selfdestruction of life as we witness in The World of Nagaraj. Youngsters' behavior and strange activities put elders in a very pathetic condition. They are like fish in troubled water. Nagaraj felt very uneasy and disturbed to answer Gopu for his questions about Tim's secret activities. He, too, was embarrassed when he found that Tim's dropout from college was detected by his father. He was completely broken at the moment he felt that it was very difficult to answer such uncomfortable questions.

Thus, Narayan has spoken about the psychic trauma of youngsters in detail with the help of characters and dialogues. He has made use of effective language skills to present things effectively. No writer before or during or after Narayan's period had the courage and intellect to speak about such issues in a way so that any reader could easily perceive them.

Tim's character has been speaking truths of life in a realistic manner. Any youngster,s for that matter, will have to go through the path of such difficulties and obstacles in their life. Narayan has taught the young society to realize the truth and live a life so meaningful and useful for ourselves, parents, and friends. If they undergo any such psychic trauma, their elders and parents must help them in overcoming it.

Thus, Narayan has mirrored the morals of life through his work, The World of Nagaraj. His intellect has once again gained well appreciation from readers from all disciplines of life. His works are more realistic and pragmatic. He tries to guide the readers in the right way by revealing the hidden truths of life. His approach seems to be more psychological compared to others when it comes to novel making. The World of Nagaraj has proved to be a psychological novel that explores a thematic world. It engrosses the real world of the youngsters and the practical issues faced by them at various stages of their life.

\section{References}

Bhaduri, Leena Sarkar. "Psychological Interpretation of R.K.Narayan's The Bachelor of Arts." International Journal of English and Literature, vol. 6, no. 2, 2016, pp. 27-30.

Narayan, R.K. The Bachelor of Arts, Vintage, 2000.

Narayan, R.K. The World of Nagaraj, Penguin Random House, 1990.

"Psychological Trauma." Wikipedia, https:// en.wikipedia.org/wiki/Psychological_trauma.

Putatunda, Sarbani. R.K.Narayan: Critical Essays, Prentice Hall India Learning, Pvt. Ltd., 2012.

"R.K. Narayan." Wikipedia, https://en.wikipedia. org/wiki/R._K._Narayan.

"The World of Nagaraj." Wikipedia, https:// en.wikipedia.org/wiki/The_World_of_ Nagaraj.

\section{Author Details}

Gabriel Karthick K, Assistant Professor of English, Voorhees College, Vellore, Tamil Nadu, India, Email ID: karthick.krish@rocketmail.com 